\title{
General IFLA Resource List
}

\section{IFLA manifestos}

IFLA. (1995). IFLA/UNESCO Public Library Manifesto, The Hague: IFLA. (http://www.ifla.org/VII/s8/unesco/manif.htm)

IFLA. (1999). IFLA/UNESCO School Library Manifesto. (http://www.ifla.org/en/publications/iflaunesco-school-library-manifesto-1999) IFLA. (2002). The IFLA Internet Manifesto. (http://www.ifla.org/publications/theifla-internet-manifesto)

\section{IFLA standards and guidelines}

Cylke, F., Byrne, W., Fiddler, H., Zharkov, S.S., and IFLA Section of Libraries for the Blind, Standards Development Committee. (1983). Approved recommendations on working out national standards of library services for the blind. The Hague: IFLA, 1983.

Day, J.M., and IFLA Section for Libraries Serving Disadvantaged Persons. (2000). Guidelines for library services to deaf people, $2^{\text {nd }}$ ed. Professional report \#62. The Hague: IFLA.

IFLA Libraries for Children and Young Adults Section. (2003). Guidelines for Children's Libraries Services. The Hague: IFLA.

(http://www.ifla.org/en/publications/guidelines-for-childrens-libraryservices)

IFLA Libraries for Children and Young Adults Section. (2007). The Guidelines for Library Services to Babies and Toddlers. The Hague: IFLA. (http://archive.ifla.org/VII/d3/pub/Profrep100.pdf)

IFLA Section for Library Services to Multicultural Populations. (2009). Multicultural communities: guidelines for library services, $3^{\text {rd }}$ ed. The Hague: IFLA.

(http://www.ifla.org/en/publications/multicultural-communities-guidelinesfor-library-services-3rd-edition)

IFLA Section of Public Libraries. (1998). The public library as the gateway to the information society: the revision of the IFLA guidelines for public libraries, proceedings of the IFLA/ UNESCO Pre-Conference Seminar on Public Libraries, 1997. The Hague: IFLA. 
Kavanaugh, R., Skold, B.C., and IFLA Section of Libraries Serving Persons with Print Disabilities. (2005). Libraries for the blind in the information age: Guidelines for development. The Hague: IFLA.

(http://www.ifla.org/en/publications/ifla-professional-reports-86)

Lehmann, V., Locke, J., and IFLA Section for Libraries Serving Disadvantaged Persons. (2005). Guidelines for library services to prisoners, $3^{\text {rd }}$ ed. Professional report \#34. The Hague: IFLA.

(http://archive.ifla.org/VII/s9/nd1/iflapr-92.pdf)

Muller, P., Chew, I., and IFLA Section of Libraries for Children and Young Adults. (2008). Guidelines for Library Services for Young Adults The Hague: IFLA.

(http://www.ifla.org/en/publications/revised-guidelines-for-library-services-foryoung-adults) ch 3

Nielsen, G. S., Irvall, B., and IFLA Section of Libraries for Disadvantaged Persons. (2001). Guidelines for library services to persons with dyslexia. The Hague: IFLA. (http://archive.ifla.org/IV/ifla72/papers/101-Nielsen-en.pdf)

Panella, N.M., and IFLA Section for Libraries Serving Disadvantaged Persons. (2000). Guidelines for libraries serving hospital patients and the elderly and disabled in long-term care facilities. Professional report \#61. The Hague: IFLA.

(http:/ / archive.ifla.org/VII/s9/nd1/iflapr-61e.pdf)

Pestell, R., and IFLA Mobile Libraries Round Table. (1991). Mobile library guidelines. Professional report \#28. The Hague: IFLA.

\section{IFLA reports}

IFLA. (n.d.) The IFLA/UNESCO Multicultural Library Manifesto.

(http://www.ifla.org/en/publications/iflaunesco-multicultural-library-manifes to)

IFLA. (n.d.) Professional codes of ethics for librarians.

(http:/ /www.ifla.org/en/faife/professional-codes-of-ethics-for-librarians)

IFLA Public Libraries Section. (n.d.) Acts on library services.

(http://www.ifla.org/V/cdoc/acts.htm)

IFLA Public Libraries Section. (2008). Meeting User Needs: A checklist for best practice produced by section $8-$ public libraries section of IFL $A$.

(http://www.ifla.org/VII/s8/proj/Mtg_UN-Checklist.pdf)

IFLA Section for Public Libraries. (2003) The Role of Libraries in Lifelong Learning. Final report of the IFL A project under the Section of Public Libraries

(http://www.ifla.org/en/publications/the-role-of-libraries-in-lifelong-learning)

IFLA Section of School Libraries and Resource Centers. (2002). The IFLA/ UNESCO School Library Guidelines 2002.

(http:/ / www.ifla.org/en/publications/the-iflaunesco-school-library-guidelines2002) 
Yarrow, A., Clubb, B., Draper, J., and IFLA Public Libraries Section. (2008). Public Libraries, Archives and Museums: Trends in Collaboration and Cooperation. Professional reports, \#108. The Hague: IFLA.

(http://www.ifla.org/en/publications/ifla-professional-reports-108) 
